\title{
PENGETAHUAN MASYARAKAT TENTANG BARANG ELEKTRONIK BEKAS (E WASTE) DI KOTA SEMARANG
}

\author{
Anief Rufiyanto ${ }^{1}$, Widi Astuti ${ }^{2}$ \\ ${ }^{1}$ Teknik Elektronika Fakultas Teknik Universitas Pandanaran \\ ${ }^{2}$ Teknik Lingkungan Fakultas Teknik Universitas Pandanaran \\ Jalan Banjarsari Barat No 1 Pedalangan, Banyumanik, Semarang, Indonesia \\ Email: widi_unp@yahoo.co.id \\ aniefrufiyanto@gmail.com
}

\begin{abstract}
Indonesian is one of the largest consumers of home electronics in Asia. It is therefore conceivable that in the next few years Indonesian will experience $E$-Waste booming. This does not include the amount of E-Waste entering Indonesian illegally from some developed countries. From the results of a preliminary survey conducted by the BCRCSEA Jakarta in 2007, compared to other developing countries in Southeast Asia, people awareness towards the problems of E-Waste in Indonesian is relatively left behind. This study attempts to analyze public perceptions and behavior towards waste and the factors that influence waste management in Semarang. This study also tries to find out how much the public's willingness to engage in recycling electronic waste. The findings showed that public perception in Semarang toward E-Waste and its recycling considered low. While most of respondents preferred to get service and reparation for their out of order electronics. Respondents argued that E-Waste recycling will merely benefit certain parties. It also due to respondents' low knowledge on E-Waste and its recycling. Most respondents, however, stated that they were ready to participate in recycling E-Waste, with expenditure around Rp5,000,- up to Rp10,000,-. From the study results, demografic variable influenced respondents' perception and behavior, though it was insignificant. Whereas factors that shaped and influenced public's willingness in Kota Semarang to be involved in E-Waste recycling was respondent's assessment concerned to current environmental condition, public perception and behavior toward E-Waste dan its recycling effort, the cost in carrying out $E$-Waste recycle process, and their knowledge about $E$-Waste and its recycle possibility.
\end{abstract}

Key Word : E-Waste, recycle, perception and behavior, willingnes

\section{PENDAHULUAN}

Pada era informasi ini, barang-barang elektronik seperti komputer, telepon genggam, tape recorder, VCD player, laptop, AC, kipas angin, mesin cuci, lemari es dan televisi bukanlah barang yang baru lagi. Barang-barang elektronik tersebut saat ini menjadi kebutuhan baik penduduk kota, maupun masyarakat yang tinggal di pelosok desa sekalipun. Bahkan untuk sebagian orang barang elektronik, menganggap sebagai kebutuhan pokok yang harus tersedia. Di negara-negara berkembang yang memiliki perekonomian rendah sangat berpeluang bagi negara maju untuk membuang sampah elektronik mereka 
dengan alih-alih penjualan barang dengan harga yang sangat murah. Sehingga barangbarang elektronik dapat dijangkau oleh seluruh lapisan masyarakat di negara berkembang.

Di negara-negara maju, pemerintah telah menerapkan berbagai peraturan untuk mengelola limbah eletronik, misalnya melalui aturan yang mengharuskan produsen melakukan penarikan barang-barang elektronik yang diproduksi dan programprogram pengumpulan sampah elektronik. Menurut Hanafi dkk (2011), sebagai contoh di Jerman telah memiliki organisasi bantuan lingkungan dimana sejak delapan tahun lalu bersama perusahaan yang bergerak dibidang telekomunikasi Jerman, sudah memulai aksi pengumpulan telepon seluller bekas. Aksi ini ternyata sangat menguntungkan karena dapat menghemat bahan baku yang semakin langka. Masih menurut Hanafi dkk (2011) sedangkan di negara Amerika sudah mempunyai peraturan yang tidak memperbolehkan penduduknya untuk membuang komputer bekas (E Waste) di tempat pembuangan sampah. Menurut Damanhuri dan Sukandar (2006), permasalahan E Waste di Indonesia tidak hanya melibatkan sektor formal saja, tetapi terungkap bahwa peran sektor informal sangat besar. Hal ini disebabkan istilah $\mathrm{E}$ Waste masih belum akrab bagi kebanyakan orang di Indonesia

\section{RUMUSAN MASALAH}

Dari permasalahan tersebut, beberapa pertanyan penelitiuan dapat disimpulkan sebagai berikut :

a. Apakah masyarakat menyadari bahwa $E$ Waste berbahaya bagi kesehatan dan lingkungan?

b. Apakah masyarakat mengetahui lingkungannya sudah tidak sehat dengan kehadiran E Waste?

c. Bagaimana pendapat dan pandangan masyarakat di Kota Semarang terhadap E Waste?

d. Bersediakah masyarakat untuk merubah gaya hidupnya terhadap E Waste? e. Bersediakah masyarakat berperan serta dalam pengelolaan $E$ Waste?

Berdasarkan pertanyaan penelitian tersebut peneliti mencoba menelaah berbagai aspek untuk mengetahui pengetahuan masyarakat tentang $E$ Waste dan kesediaannya untuk melakukan pengelolaan di Kota Semarang.

2. RUANG LINGKUP PENELITIAN

Penelitian dilakukan di Kota Semarang, yang dalam penelitian ini dibagi menjadi 4 wilayah yaitu :

a. Wilayah Semarang bagian utara diwakili oleh Kecamatan Semarang Utara

b. Wilayah Semarang bagian barat diwakili oleh Kecamatan Semarang Barat, Kecamatan Semarang Tengah, Kecamatan Tugu dan Kecamatan Ngaliyan.

c. Wilayah Semarang bagian selatan diwakili oleh Kecamatan Candisari, Kecamatan Gajahmungkur, Kecamatan Banyumanik, Kecamatan Gunungpati.

d. Wilayah Semarang bagian timur diwakili oleh Kecamatan Semarang Timur, Kecamatan Pedurungan, Genuk dan Gayamsari.

Dalam penelitian ini limbah elektronik yang dibatasi menjadi empat kategori (Hanafi dkk 2011), yaitu :

a. Gagdet : handphone, VCD player

b. Small appliances :hairdryer, blender,toaster

c. Medium appliances: TV, komputer, video player

d. Large appliances : kulkas, mesin cuci

\section{METODE PENELITIAN}

1. Lokasi Penelitian

Penelitian ini dilakukan di Kota Semarang, Propinsi Jawa Tengah dengan gambar wilayah pada gambar dibawah ini. Dari perhitungan dan keterbatasan peneliti maka pengambilan sampel dilakukan dengan metode sampel kluster (cluster sampling) dimana wilayah Kota Semarang 
berdasarkan kepadatan penduduk seperti pada tabel 1.

Tabel 1. Penentuan jumlah sampel responden masyarakat

\begin{tabular}{rlrlr} 
No & Kecamatan & Jumlah KK & \multicolumn{2}{c}{ Sampel } \\
\hline 1 & Banyumanik & 35529 & 16,95 & 61 \\
\hline 2 & Tembalang & 43197 & 20,60 & 89 \\
\hline 3 & Pedurungan & 54512 & 26,00 & 141 \\
\hline 4 & Semarang Barat & 44302 & 21,13 & 93 \\
\hline 5 & Semarang Utara & 32108 & 15,32 & 50
\end{tabular}

Data dan Instrumen

Data Primer :

Data ini adalah data yang diperoleh langsung dari responden yang meliputi :

a. Faktor karakteristik responden, meliputi umur, jenis kelamin, pendidikan, jenis pekerjaan, jumlah anggota keluarga, struktur umur dalam keluarga, agama dan kepercayaan serta status dan peran sosial

b. Faktor sosial budaya responden, meliputi interpretasi responden terhadap hakekat lingkungan dan interpretasi responden terhadap lingkungan dalam ajaran agamanya.

c. Faktor psikologi responden, meliputi kebiasaan, keyakinan, motivasi responden dalam kesediaannya terlibat dalam daur ulang $\mathrm{E}$ Waste, persepsi responden terhadap E Waste, perilaku responden terhadap E Waste, persepsi responden terhadap daur ulang E Waste, perilaku responden terhadap daur ulang $\mathrm{E}$ Waste

d. Faktor pengetahuan responden responden, meliputi pengetahuan responden tentang barang-barang elektronik, pengetahuan responden, tentang $\mathrm{E}$ Waste dan pengetahuan responden tentang daur ulang $\mathrm{E}$ Waste

Data sekunder

Data ini diperoleh dari pencatatan di Badan Pusat Statistik (BPS) Kota Semarang. Teknik Penyajian dan Analisa Data
Pengolahan data terhadap kuesioner yang telah disebar dan telah dikembalikan, dilakukan perhitungan kembali dan merekap jumlahnya. Kemudian data tersebut dikelompokkan menurut variabel yang telah ditentukan dengan menggunakan penyekoran untuk mengukur besarnya indikator penelitian. Analisa dilakukan untuk data kualitatif dan data kuantitatif dengan menggolongkan data faktor individu, faktor dasar dan faktor pendorong. Setelah itu dilakukan penghitungan jawaban dan diprosentasekan berdasarkan golongan jawabannya. Dalam melakukan analisa data digunakan tiga metoda yaitu :

a. Analisis statistik deskriptif yaitu metode yang digunakan untuk menghitung skor rata-rata dari sejumlah indikator yang dinyatakan dengan sebaran frekwensi baik dalam angka mutlak maupun persentase

b. Analisis statistik induktif yaitu metode yang digunakan untuk menguji hubungan antar variabel yang saling berpengaruh dengan menggunakan uji crosstab dengan aplikasi software SPSS 17, sedangkan untuk mengetahui faktorfaktor yang berpengaruh terhadap kesediaan responden dengan menggunakan analisa faktor dengan metode Principal Component Analysis pada software SPSS 17.

\section{HASIL DAN PEMBAHASAN}

Karakteristik Responden 
Karakteristik responden dalam penelitian ini terdapat tujuh indikator yaitu umur, jenis kelamin, pendidikan, jenis pekerjaan, struktur umur dalam keluarga, agama dan kepercayaan serta status dan peran sosial. Dari hasil survey diperoleh karakteristik responden seperti yang terlihat pada tabel 2 .

Tabel 2 : Karakteristik Responden di wilayah penelitian

\begin{tabular}{|c|c|c|c|}
\hline Variabel & Indikator & Frekuensi & Presentase \\
\hline \multirow[t]{3}{*}{ Umur } & Anak-anak & 0 & 0 \\
\hline & Dewasa & 308 & 94,46 \\
\hline & Tua & 91 & 5,54 \\
\hline \multirow[t]{2}{*}{ Jenis Kelamin } & Laki-laki & 308 & 77,19 \\
\hline & Perempuan & 91 & 22,81 \\
\hline \multirow[t]{5}{*}{ Pendididikan } & $\mathrm{SD}$ & 44 & 110,3 \\
\hline & SLTP & 20 & 5,01 \\
\hline & SLTA & 227 & 56,89 \\
\hline & $\mathrm{S} 1$ & 73 & 18,30 \\
\hline & $\mathrm{S} 2$ & 35 & 8,77 \\
\hline \multirow[t]{9}{*}{ Pekerjaan } & Pelajar/Mahasiswa & 21 & 5,28 \\
\hline & PNS & 32 & 4,32 \\
\hline & Wiraswasta & 60 & 8,11 \\
\hline & Swasta & 173 & 23,38 \\
\hline & Pengusaha & 2 & 0,29 \\
\hline & Dosen/guru & 3 & 0,75 \\
\hline & Pedagang & 45 & 1,62 \\
\hline & Jasa & 19 & 2,57 \\
\hline & Lain-lain & 45 & 6,08 \\
\hline \multirow[t]{3}{*}{ Pendapatan } & $<\operatorname{Rp~1.500.000,00}$ & 141 & 21,96 \\
\hline & $\begin{array}{c}\text { Rp } 1.500 .000,00- \\
\text { Rp 3.000.000,00 }\end{array}$ & 134 & 20,87 \\
\hline & $>\operatorname{Rp} 3.000 .000,00$ & 123 & 19,16 \\
\hline \multirow[t]{3}{*}{ Status Tempat Tinggal } & Rumah sendiri & 301 & 75,44 \\
\hline & Kontrak/kost & 96 & 24,06 \\
\hline & Asrama & 1 & 0,25 \\
\hline \multirow[t]{5}{*}{ Luas Bangunan } & $<36 \mathrm{~m} 2$ & 0 & 0 \\
\hline & $36 \mathrm{~m} 2-45 \mathrm{~m} 2$ & 301 & 75,44 \\
\hline & $45 \mathrm{~m} 2-72 \mathrm{~m} 2$ & 96 & 24,06 \\
\hline & $72 \mathrm{~m} 2-200 \mathrm{~m} 2$ & 1 & 0,25 \\
\hline & $>200 \mathrm{~m} 2$ & 1 & 0,25 \\
\hline \multirow[t]{6}{*}{ Jumlah Anggota Keluarga } & 3 & 68 & 17,13 \\
\hline & 4 & 181 & 45,58 \\
\hline & 5 & 106 & 26,70 \\
\hline & 6 & 23 & 5,79 \\
\hline & 7 & 8 & 2,02 \\
\hline & 8 & 7 & 1,76 \\
\hline
\end{tabular}




\begin{tabular}{llll}
\hline Variabel & Indikator & Frekuensi & Presentase \\
\hline
\end{tabular}

Sumber : hasil survei lapangan, 2015

Pengetahuan Masyarakat terhadap E Waste Persepsi Masyarakat Kota Semarang terhadap E Waste

$$
\text { Untuk mengetahui persepsi }
$$
masyarakat Kota Semarang terhadap $E$ Waste dalam penelitian ini diawali dengan penilaian masyarakat terhadap kualitas Kota Semarang saat ini. Sebagian besar responden $(72,2 \%)$ menilai kualitas lingkungan saat ini di Kota Semarang adalah buruk. Mereka juga setuju $(71,0 \%)$ saat ini terjadi penurunan kualitas lingkungan. Penurunan kualitas tersebut sebagian besar responden menyebutkan karena semakin bertambahnya jumlah penduduk sehingga meningkatkan jumlah sampah, terjadinya pencemaran udara dan air dari industri dan terjadinya rob. Sedangkan apabila penurunan tersebut salah satunya dampak dari $E$ Waste, sebanyak $50,6 \%$ responden setuju sedangkan $37,7 \%$ menyatakan tidak setuju yang ditunjukkan pada tabel berikut.

Tabel 3. Prosentase Persepsi Masyarakat Kota Semarang terhadap E Waste

\begin{tabular}{|l|c|c|}
\hline \multirow{2}{*}{ Indikator dan spesifikasinya } & \multicolumn{2}{|c|}{ Prosentase frekwensi } \\
\cline { 2 - 3 } & Mutlak & Relatif \\
\hline 1. Kualitas Kota Semarang saat ini: & & \\
a. Sangat baik & 1 & 0,6 \\
b. Baik & 19 & 11,7 \\
c. Tidak tahu & 117 & 8,0 \\
d. Buruk & 2 & 72,2 \\
e. Sangat buruk & & 1,2 \\
2. Terjadi penurunan kualitas & & \\
lingkungan Kota Semarang saat ini: & 2 & 1,2 \\
a. Sangat tidak setuju & 20 & 12,3 \\
b. Tidak setuju & 12 & 7,4 \\
c. Tidak tahu & 115 & 71,0 \\
d. Setuju & 4 & 2,5 \\
e. Sangat setuju & & \\
3. Penurunan terjadi dampak dari $E$ & 2 & 0,6 \\
Waste: & 61 & 37,7 \\
a. Sangat tidak setuju & 16 & 9,9 \\
b. Tidak setuju & 82 & 50,6 \\
c. Tidak tahu & 2 & 1,2 \\
d. Setuju & & \\
e. Sangat setuju & & \\
& & \\
\hline
\end{tabular}

Sumber : hasil survei lapangan, 2015

Dalam penelitian ini persepsi masyarakat Kota Semarang terhadap $E$ Waste tergolong buruk, hal ini dapat dilihat dari sebaran frekwensi responden seperti dalam tabel 4 
Tabel 4. Sebaran Frekwensi Persepsi Masyarakat Kota Semarang terhadap E Waste

\begin{tabular}{|c|c|c|}
\hline \multirow{2}{*}{ Skor } & \multicolumn{2}{|c|}{ Frekwensi } \\
\cline { 2 - 3 } & Mutlak & Relatif \\
\hline 3 & 19 & 11,7 \\
5 & 4 & 2,5 \\
6 & 9 & 5,6 \\
9 & 38 & 23,5 \\
10 & 23 & 14,2 \\
12 & 69 & 42,6 \\
\hline & & \\
\hline Rata-rata skor : 9,48 Skala : 6- 19 & Kategori : Buruk \\
\hline
\end{tabular}

Sumber : hasil survei lapangan, 2015

Persepsi Masyarakat Kota Semarang

terhadap Daur Ulang E Waste

Dari hasil penelitian dapat dilaporkan bahwa sebagian besar responden tidak mengetahui tujuan dan manfaat dari daur ulang $E$ Waste. Sebanyak 31,5\% responden juga tidak mengetahui bahwa tujuan daur ulang salah satunya menguntungkan secara lingkungan (Tabel 5). Sebagian responden berpendapat bahwa daur ulang $E$ Waste hanya menguntungkan pihak-pihak tertentu, mereka juga ragu-ragu kalau manfaat daur ulang $E$ Waste menguntungkan secara ekonomi bagi konsumen atau pengguna. Responden beranggapan lebih memilih menggunakan barang-barang elektronik yang mempunyai kriteria pembelian tertentu daripada melakukan daur ulang. .E Waste juga tidak ditemukan di Tempat Pembuangan Akhir (TPA) sampah. Hal ini disebabkan karena adanya aliran E Waste di masyarakat pada sektor informal yang dilakukan oleh jasa perbaikan dan perdagangan secondhand (Wahyu.dkk, 2009). Kriteria pembelian yang dipakai konsumen biasanya adalah barang-barang elektronik yang hemat energi. Mereka beranggapan pemilihan tersebut lebih nyata keuntungannya, meskipun mereka juga tidak banyak mengetahui kriteia produk yang hemat energi. Selain itu juga ada yang beranggapan lebih memilih produk yang dipromosikan sebagai produk yang ramah lingkungan. Seperti dalam penelitian yang dilakukan oleh Hanafi (2011) untuk responden di DKI Jakarta, responden lebih memilih produk elektronik yang hemat energi dan yang dapat dipercaya, bukan untuk kepentingan lingkungan namun untuk kepentingan ekonomi. 
Tabel 5. Prosentase Persepsi Masyarakat Kota Semarang terhadap Daur Ulang E Waste

\begin{tabular}{|l|c|c|}
\hline \multirow{2}{*}{ Indikator dan spesifikasinya } & \multicolumn{2}{|c|}{ Prosentase frekwensi } \\
\cline { 2 - 3 } & Mutlak & Relatif \\
\hline 1. Tujuan daur ulang E Waste & 3 & 0,6 \\
a. Sangat baik & 54 & 33,3 \\
b. Baik & 32 & 19,8 \\
c. Tidak tahu & 71 & 43,8 \\
d. Tidak baik & 2 & 1,2 \\
e. Sangat tidak baik & & \\
& & 0,6 \\
2. Manfaat daur ulang E Waste: & 1 & 33,9 \\
a. Sangat tidak bermanfaat & 55 & 19,1 \\
b. Tidak bermanfaat & 31 & 42,6 \\
c. Tidak tahu & 69 & 1,2 \\
d. Bermanfaat & 2 & \\
e. Sangat bermanfaat & & 0,3 \\
& & 31,5 \\
3. Daur ulang $E$ Waste menguntungkan & & 19,1 \\
lingkungan : & 5 & 43,2 \\
a. Sangat tidak setuju & 51 & 4,3 \\
b. Tidak setuju & 31 & \\
c. Tidak tahu & 70 & \\
d. Setuju & 7 & \\
e. Sangat setuju & & \\
\hline
\end{tabular}

Sumber : hasil survei lapangan, 2015

Sedangkan berdasarkan sebaran frekwensinya, persepsi masyarakat Kota Semarang terhadap daur ulang $E$ Waste tergolong buruk, hal ini dapat dilihat dalam Tabel 6.

Tabel 6. Sebaran Frekwensi Persepsi Masyarakat Kota Semarang terhadap Daur Ulang E Waste

\begin{tabular}{|c|c|c|}
\hline \multirow{2}{*}{ Skor } & \multicolumn{2}{|c|}{ Frekwensi } \\
\cline { 2 - 3 } & Mutlak & Relatif \\
\hline 3 & 56 & 34,5 \\
5 & 1 & 20,0 \\
6 & 30 & 18,5 \\
10 & 2 & 1,2 \\
12 & 73 & 45,1 \\
& & \\
\hline Rata-rata skor : 7,71 & Skala : $6-19$ & Kategori : Buruk \\
\hline
\end{tabular}

Sumber : hasil survei lapangan, 2015 
Faktor-Faktor yang Mempengaruhi Perilaku Masyarakat Kota Semarang terhadap Kesediaannya Terlibat dalam Daur Ulang $E$ Waste

Dari hasil pengolahan data yang telah dilakukan dapat diketahui beberapa indikator yang saling berpengaruh satu sama lainya. Variabel demografi yang diteliti antara lain usia, jenis kelamin, pendidikan, kondisi tempat tinggal dan pendapatan. Dari kelima indikator demografi tersebut berpengaruh terhadap kesediaan responden untuk terlibat dalam daur ulang $E$ Waste tetapi tidak secara signifikan. Usia responden tidak berpengaruh secara signifikan hal ini disebabkan mayoritas responden berusia antar 14 - 55 tahun yang tersebar tidak merata dan rentang usia yang cukup panjang. Hal ini sedikit berbeda dengan penelitian yang dilakukan oleh Hanafi (2011), usia responden yang bersedia untuk terlibat dalam daur ulang berkisar antara 21 - 30 tahun yang berpengaruh juga tetapi tidak signifikan. Indikator jenis kelamin berpengaruh secara signifikan meskipun sangat kecil. Hasil penelitian ini menunjukkan responden laki-laki lebih bersedia untuk melakukan daur ulang dibandingkan dengan responden perempuan, meskipun dalam hal ini disebabkan juga oleh perbandingan responden laki-laki dan perempuan yang tidak seimbang. Jumlah responden laki-laki $(65,3 \%)$ lebih banyak dibandingkan dengan responden perempuan $(34,7 \%)$.

Pendidikan sebagai salah satu indikator dalam penelitian ini juga tidak berpengaruh secara signifikan. Diharapkan semakin tinggi tingkat pendidikan semakin baik persepsi dan perilakuknya terhadap lingkungan. Kondisi pendidikan responden di Kota Semarang termasuk pada kategori yang sudah baik, mengingat responden berpendidikan SLTP hanya sekitar 10,2\% sedangkan sisanya SLTA dan perguruan tinggi. Hal ini berbeda dengan penelitian yang dilakukan oleh Hanafi (2011), pendidikan masyarakat di DKI Jakarta mempunyai pengaruh yang signifikan terhadap kesediaan responden untuk terlibat dalam daur ulang. Hal ini disebabkan mayoritas responden berpendidikan perguruan tinggi. Demikian juga seperti yang dinyatakan oleh Hanafi (2011) Kondisi tempat tinggal juga sebagai faktor yang berpengaruh terhadap kesediaan responden dalam melakukan daur ulang, tetapi tidak signifikan. Asumsi yang dapat diajukan disini adalah dengan status rumah sewa maka responden akan lebih bersedia melakukan daur ulang dibandingkan dengan mereka memiliki sendiri rumah yang berstatus hak milik. Karena sebagian besar responden $(85,4 \%)$ tinggal dengan status rumah hak milik sendiri, dengan alasan akan lebih memilih untuk menyimpan barangbarang elektroniknya yang sudah rusak. Tetapi pada kenyataannya hanya $37,1 \%$ yang setuju untuk menyimpan.

Pendapatan responden dalam hal ini adalah penghasilan dari pekerjaan responden yang diterima per bulan berpengaruh tetapi tidak secara signifikan. Dalam hal ini peneliti beranggapan semakin tinggi pendapatan maka semakin bersedia untuk terlibat dalam daur ulang $E$ Waste.

Dari hasil penelitian responden yang berasal dari Semarang Utara yang mayoritas pendapatannya rendah $(56,3 \%)$, namun kesediaanya untuk melakukan daur ulang lebih tinggi dibandingkan dengan responden di Semarang Selatan. Dilihat dari tingkat pendapatan dan pendidikan responden Semarang Selatan cukup tinggi, tetapi kesediaannya untuk melakukan daur ulang terkategori cukup.

Dari hasil penelitian dan pengolahan data yang telah dilakukan kesediaan masyarakat Kota Semarang untuk melakukan daur ulang $E$ Waste dipengaruhi oleh empat variabel yaitu, penilaian responden terhadap kondisi lingkungan saat ini di Kota Semarang, persepsi dan perilaku masyarakat terhadap $E$ Waste dan daur ulangnya, besarnya biaya untuk daur ulang $E$ Waste dan pengetahuan $E$ Waste dan daur 
ulangnya. Hal ini sedikit berbeda dengan penelitian yang dilakukan oleh Hanafi (2011) untuk penduduk DKI Jakarta, terdapat empat variabel yang berpengaruh yaitu uang dan lingkungan, perilaku terhadap lingkungan, aktifitas bagi lingkungan dan perioritas terhadap lingkungan dan ekonomi.

Sebanyak $72,2 \%$ responden berpendapat bahwa kondisi lingkungan saat ini di Kota Semarang buruk dan 71,0\% menyatakan memang terjadi penurunan kualitas lingkungan. Tetapi sekitar 37,7\% responden tidak setuju apabila penurunan kualitas lingkungan tersebut akibat peningkatan $E$ Waste dan 9,9\% ragu-ragu, sedangkan yang setuju 50,6\%. Sekitar $64 \%$ dari responden mendukung dan sadar akan pelabelan untuk lingkungan. Hampir 70\% dari responden bersedia membayar untuk perbaikan lingkungan dan $80 \%$ dari mereka akan membeli produk elektronik yang ramah lingkungan. Sedangkan $61 \%$ responden memilih untuk melakukan reuse dan mendaur ulang limbah peralatan listrik dan elektronik.

Hal ini menunjukkan bahwa kesadaran lingkungan tidak sama dengan kesediaan untuk berpartisipasi dalam melindungi lingkungan dengan kegiatan daur ulang $E$ Waste yang tepat. Persepsi dan perilaku masyarakat Kota Semarang terhadap $E$ Waste dan daur ulangnya masih tergolong rendah, hal ini mempengaruhi kesediaan mereka untuk melakukan daur ulang $E$ Waste. Sebagian besar responden menganggap bahwa barang-barang elektronik yang sudah rusak bukan limbah yang berbahaya sehingga terkait dengan perilakuknya hampir semua responden memperpanjang masa pakainya. Hal ini dapat dilihat dari mayoritas responden melakukan perbaikan terhadap barangbarang elektronik mereka yang sudah rusak dengan alasan ekonomi karena untuk penghematan.

Selain itu sebagian besar dari mereka setuju apabila dilakukan daur ulang dengan dikenakan biaya, meskipun mereka masih memilih biaya yang paling rendah. Hal ini disebabkan masih rendahnya pengetahuan tentang $E$ Waste dan toksisitasnya serta mereka juga belum mengetahui tujuan dan manfaat daur ulang $E$ Waste.

\section{KESIMPULAN}

Berdasarkan penelitian yang dilakukan terhadap persepsi dan perilaku masyarakat Kota Semarang terhadap E Waste dan daur ulangnya serta kesediaannya untuk terlibat dalam daur ulang $\mathrm{E}$ Waste dapat disimpulkan Persepsi masyarakat Kota Semarang terhadap E Waste dan daur ulangnya masih rendah, perilaku terhadap barang-barang elektronik yang sudah rusak dengan melakukan perbaikan atau servis dan faktor yang terbentuk yang mempengaruhi kesediaan masyarakat Kota Semarang untuk terlibat dalam daur ulang E Waste adalah penilaian responden terhadap kondisi lingkungan saat ini di Kota Semarang, persepsi dan perilaku masyarakat terhadap E Waste dan daur ulangnya, besarnya biaya untuk daur ulang E Waste dan pengetahuan E Waste dan daur ulangnya.

\section{DAFTAR PUSTAKA :}

Damanhuri, E., dan Sukandar, 2006, Preliminary Identification of EWaste Flowin Indonesian And its Hazard Characteristic, Proceedings of Third NIES Workshop on E Waste, Japan.

Ekowaty.S., dan Damanhuri, E., 2008. Identifikasi Pola Aliran Komputer dan Komponennya di Bandung, Bandung.

Hanafi J., Helena J. Kristina, Eric Jobiliong, Agustina C., Audry V. Halim, Dwiyono Santoso, and Eliss M., 2011, The Prospects of Managing WEEE in Indonesia, The 18th CIRP Conference on Life Cycle Engineering, Braunschweig, Jerman. 
Jurnal Neo Teknika Vol.3 No 2, Desember 2017., hal.32.-41

Keputusan Presiden Nomor 61 Tahun 1993 tentang Ratifikasi Konvensi Basel

Peraturan Pemerintah (PP) No.18 Tahun 1999 jo PP No. 85 Tahun 1999 tentang

Peraturan Presiden Nomor 47 Tahun 2005 tentang Ratifikasi Ban Amandement
UU Nomor 18 Tahun 2008 tentang Pengelolaan Sampah

UU Nomor 32 Tahun 2009 tentang Perlindungan dan Pengelolaan Lingkungan Hidup

Wahyu,IM., Winardy,D., Damanhuri,E., Padmi, T., Identifikasi Material EWaste Komputer dan Komponen Daur Ulangnya di Lokasi Pengepulan E-Waste. Bandung, 2010. 